\title{
Germination of black spruce and jack pine seed at $0.5^{\circ} \mathrm{C}$
}

\author{
V. F. HAAVISTO and D. A. WINSTON
}

Canadian Forestry Service

Great Lakes Forest Research Centre

Sault Ste. Marie, Ontario

To date, success in direct seeding of black spruce (Picea mariana [Mill.] B.S.P.) has been minimal (Smithers 1965, Scott 1970). Although direct seeding is a recommended method for artifical regeneration of jack pine (Pinus banksiana Lamb.), unexplained failures have been reported (Scott 1968, 1970). A possible contributing factor in these failures is suggested here.

It has been previously reported that germination of tree seed can occur at low temperatures. MacArthur and Fraser (1963), for example, found that black spruce and white spruce (Picea glauca [Moench] Voss) seed germinated following continuous stratification for one year or more at $2^{\circ} \mathrm{C}$ $\left(35^{\circ} \mathrm{F}\right)$ and $4.5^{\circ} \mathrm{C}\left(40^{\circ} \mathrm{F}\right)$, respectively. Franklin and Krueger (1968) observed seed from true firs (Abies spp.) and mountain hemlock (Tsuga mertensiana [Bong] Carr.) germinating on the snow surface. Kao and Rowan (1970) reported germination in radiata pine (Pinus radiata D. Don) during stratification at $5^{\circ} \mathrm{C}\left(41^{\circ} \mathrm{F}\right)$. While investigating factors affecting seeding success in black spruce and jack pine, we found that seeds of both species germinated, if kept moist, at $0.5^{\circ} \mathrm{C}\left(33^{\circ} \mathrm{F}\right)$.

Five replications of 100 seeds each of black spruce and jack pine (previously stored air dry at $2^{\circ} \mathrm{C}$ for 3 years) were placed on moistened germination paper in covered glass petri dishes. These were placed in a dark cold-storage room at $0.5^{\circ} \mathrm{C}$. The number of seeds that germinated (radicles $>2 \mathrm{~mm}$ [0.1 in.] long) and the number that showed noticeable splitting and/or radicle emergence less than $2 \mathrm{~mm}$ were tallied every second week. The germination paper was kept moist by the periodic addition of distilled water which had been maintained at $0.5^{\circ} \mathrm{C}$.

Seed coats in both species began to split after about 100 days at $0.5^{\circ} \mathrm{C}$. After 255 days, $10 \%$ of the black spruce seed had radicles greater than $2 \mathrm{~mm}$ long, while only $1 \%$ of the jack pine had germinated. A further $30 \%$ of the black spruce and $24 \%$ of the jack pine seed had radicles shorter than $2 \mathrm{~mm}$ or had split seed coats as a result of imbibition processes. At this time all seeds were placed in a $23^{\circ} \mathrm{C}\left(74^{\circ} \mathrm{F}\right)$ germinating cabinet where they continued normal germination.

In a preliminary study with seeds from different seed sources we found that $9 \%$ of the black spruce and $22 \%$ of the jack pine seeds had germinated after 140 days and by 175 days the values were $13 \%$ and $43 \%$, respectively, for the two species.

As temperatures in the $0.5-2.0^{\circ} \mathrm{C}\left(33-35^{\circ} \mathrm{F}\right)$ range can occur at the ground-snow interface for long periods during winter (Haavisto and Winston, unpublished data), and as moisture is available from melting snow, seeds at such interfaces may imbibe sufficient moisture for germination to begin. If extreme cold occurs following snowmelt in the spring, germinated seeds and imbibed embryos may be physically damaged by the crystallization of internal water. Warm temperatures following snowmelt, however, may enhance developmental processes of imbibed seeds and germinates, thereby allowing for their rapid establishment.

In the study by Franklin and Krueger (1968), true fir and mountain hemlock seed were observed to germinate on the snow surface as a result of the absorption of radiant energy by the black-bodied seed. Black spruce and jack pine seed can behave in a similar manner even though air temperatures are below freezing. As the seeds heat up and imbibe moisture, they tend to settle into the snow pack. There they cool down because they are no longer well exposed to radiant heat. Again, desiccation of the imbibed embryo or germinated seedling would occur with the reduced temperatures.

The results described herein suggest that lowtemperature germination may occur under or in the snow and may contribute to the failure of direct seeding. However, if warm temperatures follow the snowmelt, rapid establishment of the cold-germinated seeds may occur, thereby enhancing the success of direct seeding.

\section{References}

FRANKLIN, J.F. and KRUEGER, K.W. 1968. Germination of true fir and mountain hemlock seed on snow. J. Forest. 66:416-417.

KAO, C. and ROWAN, K.S. 1970. Biochemical changes in seed of Pinus radiata D. Don during stratification. J. Exp. Bot. 21:869-873.

MacARTHUR, J.D. and FRASER, J.W. 1963. Low temperature germination of some eastern Canadian tree seed. Forest. Chron. 39:478-479.

SCOTT, J.D. 1968. Direct seeding. Pulp Pap. Assoc. Can., Woodl. Sec. No. 2490 (F-2).

SCOTT, J.D. 1970. Direct seeding in Ontario. Forest. Chron. 46:453-457.

SMITHERS, L.A. 1965. Direct seeding in eastern Canada, p. 15-22. In Direct seeding in the northeast. Proc. Symp., Univ. Mass., Amherst. Exp. Sta. Bull. 